\title{
THE AWARENESS OF DIVERSITY AMONG THE CZECH STUDENTS AND GRADUATES
}

\author{
JIRINCOVA, M[ilena] \& LEICHEROVA, V[eronika]
}

\begin{abstract}
This paper deals with issue of diversity and diversity management in relation to the Czech students and graduates because diversity management is a novelty in the Czech Republic and not many people and companies knowsomething more about it. At the beginning it briefly summarizes current findings of Czech and foreign authors in this area and it shows some results from researches conducted by European Union. In the next part of this paper there is described methodology that was used for own research that is presented in this paper. The main part of this paper consists from presenting data from a questionnaire survey that examines awareness of Czech students and graduates about issues of diversity and diversity management and topics relating with it.

Keywords:Benefits, Czech students, discrimination, diversity, diversity management
\end{abstract}

\section{INTRODUCTION}

As a result of globalization, of the labour market, of the changes in the society, of the demographic development, diversity management has become ever more important for whole society and the business too.[6] If a company wants to survive in this competitive environments, it has to pay attention to the diversity and make good use of its potential. Some companies in the Czech Republic begin to utilize diversity in their business but they are only an exception and not many organizations are aware of this issue. Diversity and diversity management can be connected with strategic management, human resource management, marketing and business too. The known theory of CSR also refers to diversity management [16] and it could be well used alsoin virtual enterprise paradigm.[13][14]

It is interestig to look at the awareness of young people of the issue of diversity because they are important for the future development. Therefore this article deals with this awareness and opinion on diversity of the Czech students and graduates.

\section{CRITICAL OVERVIEW}

Risberg and Sogerberg[18] define diversity as ,a mix of differences, similarities, and tensions that can exist among the elements of a collective mixture". Many authors devide the elements of diversity into primary and secondary dimensions. Primary elements of diversity often cannot be changed while the secondary elements can. This article describes diversity in terms of its primary elements- gender, age, ethnicity, mental and physical abilities and sexual orientation by the American author Hubbard [11]or Bedrnová, Nový [1]. Secondary diversity includes for example, according to Sweetman
[20], factors like socio-economic status, education, religion, geographical affiliation and marital status. Some authors state other characteristics, such as work experience, style of communication, style of work, organization roles and standards.[1]

Diversity management has a broader meaning than the diversity. This concept dates back to 1980s. It is a relatively new phenomenon in the management theory and practice and many people as well as students do not know about it anything. Some foreign universities have lessons connected with diversity or diversity management and there arise different books and monographs in this field. We don't have many publications about diversity management in the Czech Republic. As an example we can mention the twomonographs dealing entirely with diversity management "Diverzity management" from Ludvík Eger et al. [5] and "Diversity management. Comparison, the best practices of Visegrad countries" from the same author [4].

Effective implementation of the diversity strategy can bring benefits to the organization. Literature [11][18][2] most often mentions improving quality and effectiveness of the workforce, increasing creativity, innovativeness and flexibility in the organisation, improving organization image, positive changes in the organizational structure, better possibilities of recruiting and retaining talented workers, improving relationships with customers, strengthening market positions, in general competitive advantage. According to the survey Diversity for talent and competitiveness [8]the following benefits were indicated as the most significant by small and medium sized businesses - attracting, recruiting and retaining best talents $(60 \%$ of respondents), increasing creativity/innovation (45\%), increasing client's loyalty $(40 \%)$, reducing time wasted (35\%), increasing company profits (35\%) and accessing new markets (35\%) [8].

It is interesting to see what impact on company performance can diversity management bring. But it is measurable with difficulty. Some researches exist but they are often very qualitative. The topic how to measure the impact of diversity management on company performance is very broad and here is not space for it. But we can mention some authors who devote to this as Hubbard [12] with his diversity scorecard or Marr [17]with intellectual performance drivers or Kaplan [15]with perspective of learning and growth.

Very often mentioned topic connected with diversity is problem of discrimination. Different elements of diversity can be source of different types of 
discrimination. The European Union and individual states have various measures, legislation and activities against discrimination but it is still more or less widespread. See the figure No. 1 where respondents from EU and from the Czech Republic answered what type of discrimination is the most widespread. Citizens in the Czech Republic consider that age discrimination is the most widespread in their country, whereas Europeans as a whole put ethnic origin first. [7]

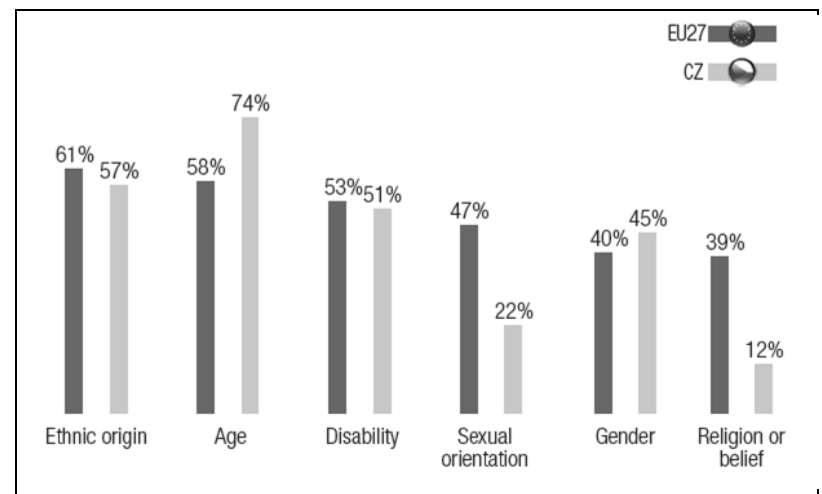

Fig. 1. Total widespread types of discrimination in the EU and in the Czech Republic

\section{METHODOLOGY AND OWN RESEARCH}

The Czech students and graduates were approached through the short questionnaire that has examined their awareness of the issue of diversity. Concretely whether they have heard about diversity or diversity management, what does it mean according to them, whether it brings some benefits to companies and what benefits and there is also question focused on discrimination and question on currently solved problem of quotas for women on board. There were closed questions and some open too. This paper works with 110 answers from young people of different ages, gender, education and environments. Data were collected since June 2012 to September 2012 throught the google docs application. Most of the respondents are women in the age of 21-25 years and the university students with economic education.

Characteristics of respondents are seen in table No. 1. The one star means absolute frequency, the two stars mean relative frequency.

\begin{tabular}{|c|c|c|c|c|}
\hline \multirow{2}{*}{ Sex } & \multicolumn{2}{|c|}{ Female } & \multicolumn{2}{|r|}{ Male } \\
\hline & $77 *$ & $0,7 * *$ & 33* & $0,3 * *$ \\
\hline \multirow{4}{*}{ Age } & \multicolumn{2}{|c|}{$15-20$ years } & \multicolumn{2}{|c|}{ 21-25 years } \\
\hline & $18 *$ & $0,16^{* *}$ & 68* & $0,62 * *$ \\
\hline & \multicolumn{2}{|c|}{ 26-30 years } & \multicolumn{2}{|c|}{ 31and more } \\
\hline & $17 *$ & $0,15^{* *}$ & $7 *$ & $0,06 * *$ \\
\hline \multirow{4}{*}{ Status } & \multicolumn{2}{|c|}{ University student } & \multicolumn{2}{|c|}{ University graduate } \\
\hline & $67 *$ & $0,61 * *$ & $35^{*}$ & $0,32 * *$ \\
\hline & \multicolumn{2}{|c|}{ High school student } & \multicolumn{2}{|c|}{ High school graduate } \\
\hline & $1 *$ & $0,01 * *$ & $7 *$ & $0,06^{* *}$ \\
\hline \multirow{6}{*}{ Field of education } & \multicolumn{2}{|c|}{ Technical } & \multicolumn{2}{|c|}{ Pedagogical } \\
\hline & 8* & $0,07 * *$ & $5 *$ & $0,05 * *$ \\
\hline & \multicolumn{2}{|c|}{ Economic } & \multicolumn{2}{|c|}{ Humanitarian } \\
\hline & 79* & $0,72 * *$ & $8 *$ & $0,07 * *$ \\
\hline & \multicolumn{2}{|c|}{ Medical } & \multicolumn{2}{|r|}{ Others } \\
\hline & 4* & $0,04 * *$ & 6* & $0,05^{* *}$ \\
\hline
\end{tabular}

Tab. 1. Distribution of respondets by sex, age, current status and field of education
Most of the respondents know what does it mean the English term "diversity" but many of them have never heard about the term of "diversity management". This is because the diversity management is used for very short time in the Czech Republic and very rarely. Czech companies as well as Czech academic community do not believe in benefits of diversity management therefore the information about issue of diversity is spreading very slowly. See the figure No. 2, where $67 \%$ of respondents have never heard about diversity management, $28 \%$ of them have heard only something about it.

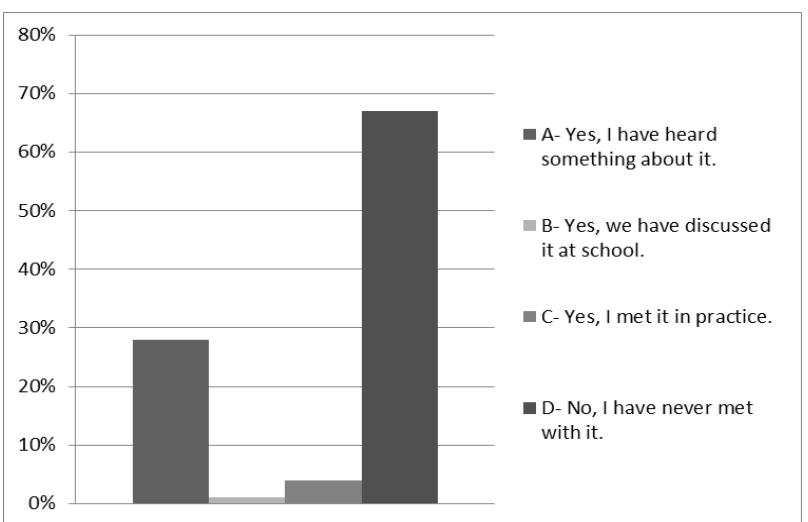

Fig. 2. The awareness about the issue of diversity management

The vast majority of respondents believe that diversity management can increase company performance. In total $94 \%$ of them answered either ,Yes, certainly" or „Yes, it is possible". They should also identify, what benefits does the using of diversity management bring. Totaly 80 of them think that the diversity management can cause better motivation, satisfaction and performance of employees and 78 respondents see the benefits of diversity management in increasing creativity and innovation. These figures are absolute because the respondents could check more options and the percent would not have so good information capability. In the figure No. 3 we can see all results of this question. These columns represet 1 . Improving the image of the company, 2. Better motivation, satisfaction, performance of employees, 3 . Retaining the best talents, 4. Increasing creativity, innovation, 5. Increasing client loyalty, 6. Increasing company profit, 7 . Access to new markets, retaining new customers, 8. Others.

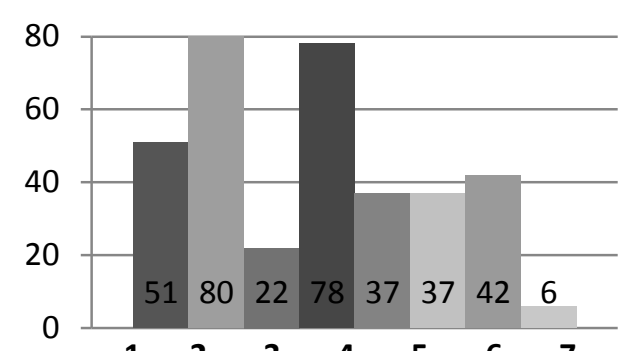

1. 2. 3. $4.5 .6 .7 \ldots$

Fig. 3. What are the benefits of diversity management?

Diversity is closely linked with discrimination. In the figure No. 1 there is seen the attidute of EU citizens and Czech citizens to the issue of discrimination. 
Respondents from the European Union answered that the most widespread type of discrimination is the discrimination based on ethnic origin, age and disability. The Czech respondents have seen the biggest discrimination in the area of age and then in the area of the ethnic origin and disability. Respondents of this own small research answered as follows.

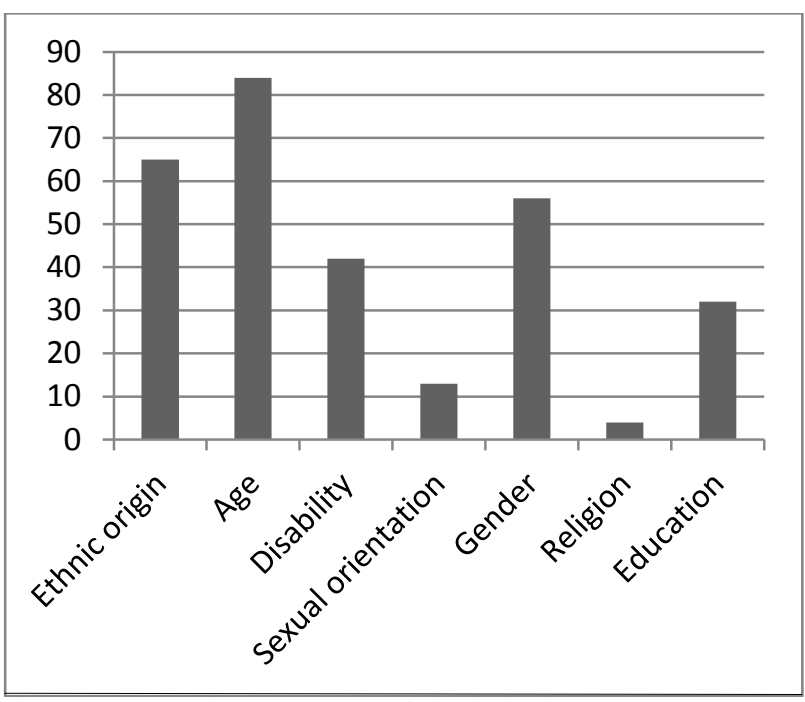

Fig. 4. The most widespread types of discrimination by respondents

We can see that the most widespread type of discrimination by the Czech students and graduates is the age discrimination. This is the same result as in the case of national research by Eurobarometer in 2009. Age problems connected with human resource management are solved also in paper of Skálová [19]. On the second position there is also ethnic origin.The issue of ethnic origin and cross-border labour mobility is solved in paper from Chebeň et al.[1] But in the third position there we can see discrimination based on gender differences- this is in contrast to the results of Eurobarometer.

It is interesting to look at the discrimination based on education. Education does not belong to the primary elements of diversity but it is very important aspect that can influence performance and motivation of employees or level of innovation and it can be also resource of discrimination. In the Czech Republic and in most of developed countries there is a trend of increasing level of education of population. By the Czech Statistical Office[10]there is increasing number of people with an university degree but also increasing number of people with no education. The high educated people often have problems in the Czech labour market because they are so called "too much qualified". It is obvious that the Czech students and graduates are seeing this problem.

The next question was also connected with discrimination. Respondents should decide which groups of people have the greatest problems in the labour market. In terms of age the greatest problems have the older people by respondents, concretely $80 \%$ of them responded in this way. But students and gratuates also perceive the discrimination of young people and graduates $(66 \%)$. High percentage of respondents $(56 \%)$ also checked the possibility of discrimination based on disability. In the figure No. 5 we can see only absolute numbers again because of more possibilities how to answer this question. It is interestig that men do not suffer from discrimination by these respondents and discrimination based on sexual orientation is really low.

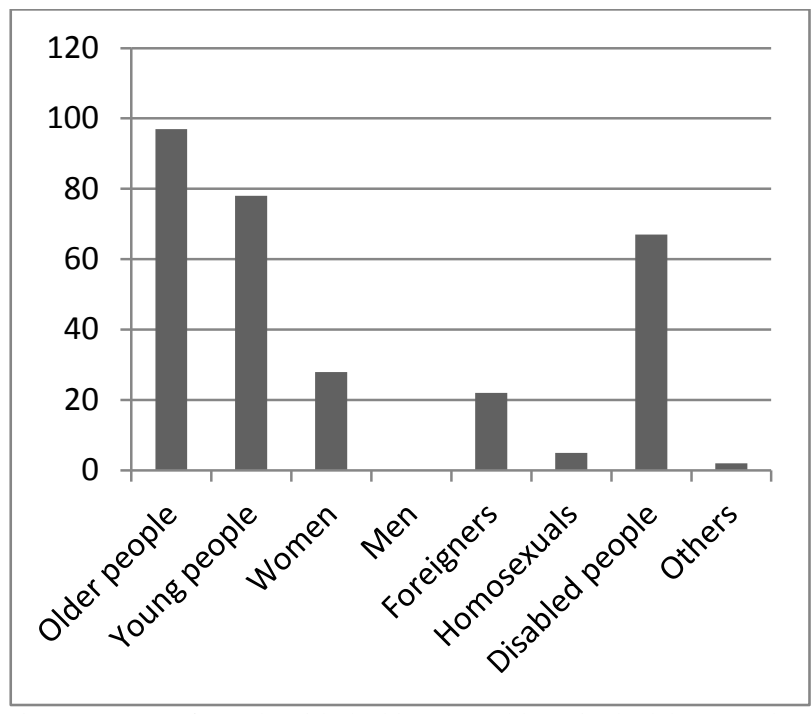

Fig. 5. Groups of people with the biggest problems in the labour market

The currently solved issue is introducing of quotas for women on board of companies in European Union listed on the Stock Exchange. Companies should voluntarily increase women's presence on corporate boards to $30 \%$ by 2015 and to $40 \%$ by 2020.[9]It is possible that there will be some legislative steps at EU level in the future and share of women or men in decision making bodies will be obligatory. Authors of this paper examined opinion of Czech students and graduates on these quotas. Czech people are generally against quotas, but respondents in this small research are open to introducing obligatory quotas, see the figure No. 6, where they should answer the question „Do you agree with introducing quotas for women in decision making bodies?".

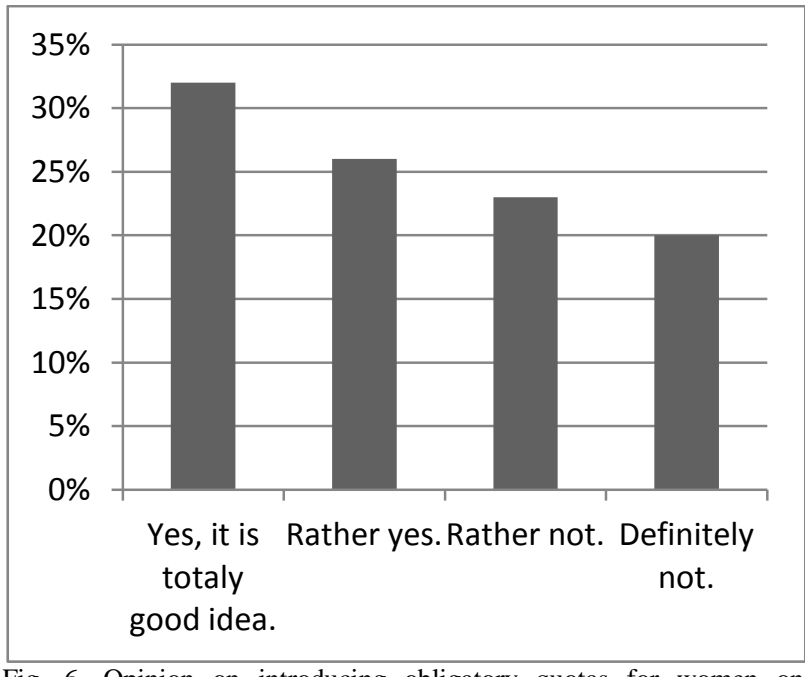

Fig. 6. Opinion on introducing obligatory quotas for women on corporate boards 


\section{CONCLUSION}

The opinion of Czech students and graduates is often similar to results from another researches. It is obvious that the issue of diversity, diversity management and its utilization is not well known in the Czech Republic. Some people only guess what this term could mean. But if they see some definition of that and find what does diversity management mean, they estimate that diversity management can bring many benefits for the company using diversity in its business and they can define it. They put in the first place benefits as increasing image of company or better motivation, satisfaction and performance of employees.

Young people in the Czech Republic are also aware of possible discrimination which can result from diversity. The most widespread discrimination by them is age discrimination. Another sources of discrimination are ethnic origin, gender or disability. Women have the biggest problems in the labour market by respondents, men have the smallest problems to find and keep a job.

Regarding quotas, there was a surprising finding because more respondents would agree with introducing quotas for women on corporate boards.

It is seen that young people are able to see the potential of diversity and diversity management. Their answers are mostly positive and most of them (78\%) would prefer in their job selection employers using diversity management.

It is seen a big potential of diversity management for companies and for academics too because there exist not so many publications and researches about it. The opinion of students and graduates is only the beginning. It could be interesting to examine also the opinion of managers or academic staff.

\section{ACKNOWLEDGEMENTS}

This paper was supported by the University of West Bohemia in Pilsen, Czech Republic. Project No. SGS2012-028: Research on the impact of monitoring, evaluation and prediction of organizational processes on the overall performance. Goal of the research project is to optimize or rationalize the overall performance of organizations through monitoring, evaluation and prediction of processes.

\section{REFERENCES}

[1] Chebeň, J.; Lančarič,D.; Savov, R. (2011). The Necessity of Implementation of Diversity Management Caused by the Actual Development of Cross-border Labour Mobility in EU. Studia commercialia Bratislavensia, Vol.4, No. 13, January 2011, p. 5064, ISSN 13377493

[2] Chebeň, J.; Lančarič, D.; Savov, R.; Lopes, P.; Barbosa, M. (2011). The Perspectives of Diversity Management in Slovakia. Faculty of International Relations Working Papers, Vol.5, No.13, p. 30,ISBN 978-80-245-1861-9

[3] Bedrnová, E., Nový, I. (2007). Psychology and sociology of management. (Psychologie a sociologie rizeni).Management Press, ISBN 978-80-7261-169-0, Praha, Czech Republic

[4] Eger, L. et al. (2012).Diversity management. Comparison, the best practices of Visegrad countries. NAVA, ISBN 978-80-7211420-7,Plzeň, Czech Republic
[5] Eger, L. et al. (2009)Diversity management. (Diverzity management). Česká andragogická společnost, ISBN 978-8087306-03-1, Praha, Czech Republic

[6] Egerová, D. (2012) Diversity management as a crucial issue of the management in the $21^{\text {st }}$ century. Problems of management in the $21^{\text {st }}$ century. Vol.3., p. 5-7. ISSN 2029-6932

[7] http://ec.europa.eu/public_opinion/archives/eb_special_320_300_ en.htm, (2009). Eurobarometr Special Surveys.Discrimination in the EU in 2009. Accessed on: 14.9.2012

[8] http://ec.europa.eu/social/search.jsp?pager.offset=50\&langId=en $\&$ searchType=null\&mode=quick\&order=null\&quickSearchKey= Diversity for talent and competitiveness, (2008).Diversity for talent and competitiveness. Materials of the European Comission. [online PDF]. Accessed on:10.7.2012

[9] http://europa.eu/rapid/pressReleasesAction.do?reference=MEMO/ $11 / 487 \&$ format $=$ HTML\&aged $=0$ \&language $=$ EN\&guiLanguage $=$ en, (2011). Europa Press releases RAPID. Accessed on:September 2012

[10] http://www.scitani.cz/sldb2011/redakce.nsf/i/predbezne_vysledky _scitani_lidu_domu_a_bytu_2011, (2012). Předběžné výsledky Sčítání lidu, domů a bytů 2011. Accessed on:13.9.2012

[11] Hubbard, E.Diversity management. (2004). HRD Press, ISBN 087425-761-1, Amherst

[12] Hubbard, E. The diversity scorecard. (2004). Elsevier Inc., S47 s. ISBN 0-7506-7457-1, Oxford

[13] Januška, M. (2011). Communication in Virtual Enterprise Paradigm. In Annals of DAAAM for 2011 \& Proceedings of the 22th international DAAAM symposium. Vienna: DAAAM International Vienna 201. p. 571-572. ISBN: 978-3-901509-83-4, ISSN: 1726-9679,Katalinic, B. (Ed.), pp. 1249 - 1250, DAAAM International Vienna, Austria

[14] Januška, M.; Kurkin, O.; Miller, A.;(2010). Communication environment for small and medium enterprises. In Business Transformation through Innovation and Knowledge Management. Istanbul, Turkey : International Business Information Management Association (IBIMA). p. 217-226. ISBN: 978-09821489-3-8

[15] Kaplan, R. S., Norton, D. P.(2004). Strategy Maps: converting intangible assets into tangible outcomes. Harvard Business School Press, ISBN 1-59139-134-2,Boston

[16] Kuldová, L.(2010).Společenská odpovědnost firem. Etické podnikáni a sociálni odpovédnost v praxi. OPS, ISBN 978-8087269-12-1, Kanina, Czech Republic

[17] Marr, B., Schiuma, G., Neely, A.(2004). The dynamics of value creation: mapping your intellectual performance drivers. Journal of Intellectual Capital, Vol. 5, No. 2,pp. 312-325, ISSN 14691930

[18] Risberg, A., Soderberg, A.-M.(2008).Translating a management concept: diversity management in Denmark. Gender in management: An International Journal, Vol 23, No 6, p. 426-441. ISSN 1754-2413

[19] Skálová,P. (2011) Population Growth and Human Resources Management, Annals of DAAAM for 2011 \& Proceedings of the 22nd International DAAAM Symposium, 23 - 26th November 2011, ISBN: 978-3-901509-83-4, ISSN: 1726-9679, Katalinic, B. (Ed.), pp. 1249 - 1250, DAAAM International Vienna, Austria

[20] Sweetman, C. (2004) Gender, Development, and Diversity. Oxfam Publishing, ISBN 0-85598-531-3, Oxford 